\title{
A POLEMICAL DISCOURSE OVER THE LEGITIMATION OF ILLEGITIMATE CHILDREN UNDER ISLAMIC LAW
}

\author{
Isa Abdur-Razaq Sarumi* \\ Azizah Bt. Mohd** \\ Norliah Bt. Ibrahim ${ }^{* * *}$
}

\begin{abstract}
Muslim jurists unanimously agree that any woman that gives birth to a child, the child is to be attributed to her husband and legitimacy of that child is to be established except in circumstances where the child is disclaimed by the husband through imprecation (li'an). However, dissension over the legitimation of children born out of wedlock has long been recorded in the classical books of Islamic Jurisprudence, although the majority of jurists' opinion secured an overwhelming preponderance over others. The argument over the legitimation has recently been advanced in order to find a feasible solution to the alarming condition of children born out of wedlock. Interestingly, both opponents and proponents of the legitimation of illegitimate children among Muslim scholars buttress their arguments with the famously narrated hadith "al-walad lil firash" ("The child is traced to the owner of the bed i.e. the legitimate husband)." on the subject matter. Therefore, this article seeks to explore juristic interpretations of the hadith and the rationale behind the scholars' dissention. This article is a result of a research that has been done through the adoption of a qualitative approach of research, which includes doctrinal and non-doctrinal legal research methodologies. It has been found that attributing a child to his putative father after the acknowledgement does not contravene the fundamental principle of Shariah; it is rather an opinion held by the majority of classical Muslim scholars.
\end{abstract}

* Ph.D Candidate, Ahmad Ibrahim Kulliyyah of Laws, International Islamic University Malaysia (IIUM), saroommool@gmail.com.

** Associate Professor, Ahmad Ibrahim Kulliyyah of Laws, International Islamic University Malaysia (IIUM), azizahmohd@iium.edu.my.

*** Associate Professor, Ahmad Ibrahim Kulliyyah of Laws, International Islamic University Malaysia (IIUM), norliah@iium.edu.my. 
Keywords: acknowledgement, al-walad lil firāsh, legitimation, putative father, status of illegitimate children

\title{
SUATU PERBINCANGAN KRITIS MENGENAI PENSAHTARAFAN ANAK-ANAK LUAR NIKAH DIBAWAH UNDANG-UNDANG ISLAM
}

\begin{abstract}
ABSTRAK
Para ilmuan Islam telah sepakat menyatakan bahawa jika seseorang perempuan yang telah berkahwin atau seorang hamba perempuan melahirkan anak, anak teresbut hendaklah di kaitkan dengan suami atau pemilik perempuan tersebut dan kesahtarafan anak tersebut akan diiktiraf. Ini akan berlaku kecuali jika suami tersebut menafikan bahawa beliau adalah bapa kepada anak tersebut melalui proses li'an. Walaubagaimanapun, terdapat perbezaan pendapat mengenai pensahtarafan anak-anak luar nikah dan ini telah banyak di bincangkan dalam buku-buku Usul Fiqah, dimana pendapat majoriti ulama-ulama mendapat sokongan yang kuat jika berbanding dengan pendapat-pendapat lain. Baru-baru ini, hujah mengenai keperluan untuk mensahtarafkan anakanak luar nikah telah diutarakan semula sebagai penyelesaian yang boleh dilaksanakan bagi mengatasi permasaalahan berat yang dihadapi oleh ramai anak-anak luar nikah. Apa yang menarik ialah kedua-dua pihak yang mencadang dan menentang penghujahan ini kedua-duanya menggunakan dasar hukum yang sama, iaitu hadis yang dikenali sebagai "al-walad lil firasy" (yang bermaksud,"Anak itu adalah dari empunya katil", yang merujuk kepada suami yang sah). Oleh itu, makalah ini bertujuan untuk meneroka tafsiran yang telah diberikan oleh para ulama hadis dan mengupas rasional yang menyebabkan terdapatnya perbezaan pendapat dikalangan mereka mengenai isu ini. Makalah ini ditulis hasil daripada penyelidikan dalam tajuk yang sama dengan menggunakan kaedah pendekatan kualitatif yang merangkumi kaedah doktrinal serta bukan doktrinal. Hasil kajian mendapati bahawa mengaitkan seorang anak kepada seseorang ayah dibeanrkan dan tidak membelakangi Syariah jika lelaki tersebut mengiktiraf perkara tersebut. Ini berdasarkan pendapat majoriti para ulama klasik.
\end{abstract}

Kata kunci: pengiktirafan, al-walad lil firasy, pensahtarafan, bapa putatif,, status anak tak sah taraf 


\section{INTRODUCTION}

Islamic law has given due consideration for the establishment of a family that the conditions attached to it are clearly stipulated in the sources Islamic legislation. The establishment of a family begins with a legal marriage, which usually results in the birth of children that usually has clearly defined familial roles and responsibilities such as determined custodianship, guardianship, inheritance and related issues. ${ }^{1}$ The establishment of genealogy is associated with the right of Allah (s.w.t), the right of the child and the father; this is why it is unlawful to attribute one's self or a child to any person other than his real father. This means that one cannot change the lineage of an adopted child and substitute the name of his real father with that of his adopted father. ${ }^{2}$

In order to safeguard against the confusion over lineages and false attribution of children, Sharı̄' ah has made the reliance on the existence of a valid marriage contract as a method for the determination of family affiliation and strongly prohibits any acts that could consume this foundation. ${ }^{3}$ However, deviation from this position sometimes occurs in the society that consequently leads to giving birth to children out of wedlock. As a result, the children born out of wedlock would be subjected to humiliation and social ill-treatment. ${ }^{4}$

The issue of legitimatimising illegitimate children has long been recorded in classical books of Islamic law. However, its discourse has always been one-sided. The tendentious approach has a tremendous impact on many contemporary writers who have shown strong

\footnotetext{
${ }^{1}$ This also includes the relationships resulting from breastfeeding and the rights that accrue to the family to claim for qisas (retaliation) if there is person is murdered or injured by another. For further reading see Sonbol, Amira alAzhary. "Adoption in Islamic society: A Historical Survey." Children in the Muslim Middle East (1995): 45-67.

${ }^{2}$ Mulla Ali al-Qārī, Mirqāt al-Mafātīh Sharhu al-Mishkât al-Masâbīh, (Beirut: Dar-Alfikr, 2010), Vol 6, 320.

${ }^{3}$ Rehman, Javaid. "The Shariah, Islamic Family Laws and International Human Rights Law: Examining the Theory and Practice of Polygamy and Talaq." International Journal of Law, Policy and the Family, no. 1 (2007): 108-127.

${ }^{4}$ Muhammad Jamil, “Istilhāq walad al-Zina fi Fiqh al-Islām $\vec{\imath}$ ' Seminar Paper on Muslim family and Contemporary Challenges held by Muslim World League, Makkah, 2010, 7.
} 
inclinations towards disregarding scholastic discourse of this topic to the extent that some have claimed that there exists aconsensus of Muslim scholars had been reached over the impermissibility of legitimation of children who are born illegitimate. This claim has catastrophic consequences on children born out of wedlock. Therefore, this article seeks to look at the legal discourse relating to the legitimatiion of children born out of wedlock within the Sunni Schools of law.

\section{JURISTIC DISCOURSE ON LEGITIMATION OF ILLEGITIMATE CHILDREN}

Muslim jurists unanimously agree that any woman (be it a married or slave-woman) who gives birth to a child, may have her husband attributed as the legal father of the child and the legitimacy of that child is to be established except when the husband refuses to acknowledge the child as being his through imprecation $\left(l i{ }^{\prime} \bar{a} n\right){ }^{5}$

Some scholars like Ibn al-Qudâmah have recorded that there is a consensus amongst the Muslim jurists that such a child would forever be attributed to the legitimate husband, whereas divergence of opinions only occurs when a child is born without his mother being in a licit relationship (firāsh), i.e., not legally married or owned by any master. This opinion is held on the basis of the famously narrated hadith " $a l$ walad lil firash" "The child is traced to the owner of the bed (i.e. the legitimate husband)." It is inferred from the hadith that when a conflict of paternity arises between a legitimate husband (owner of firāsh) and a fornicator, $(a l-z \bar{a} n i)$, the precedence must be given to the licit relationship (firāsh) over fornication, and the adulterer would be subjected to the prescribed punishment ( $h a d d) .{ }^{7}$ The Prophet ((s.a.w).) gave this historic verdict when there was a conflict between two disputing parties over a

\footnotetext{
${ }^{5}$ Muhammad Ibn Idris Al-Shāfi'i, al-Umm, (Beirut: Dar al-M'arifah, 1393), vol. 5, 2294-311. See also Billoo, Yasir. "Change and Authority in Islamic Law: The Islamic Law of Inheritance in Modern Muslim States." U. Det. Mercy L. Rev. 84 (2006): 637.

${ }^{7}$ Abdullah Ibn Ahmad Ibn Qudamah, al-Mughni, (Beirut: Dar al-Kitab al-Arabi, 1985), vol. 7, 129.
} 
paternity claim of a child in the hadith agreed upon by al-Bukhari and Muslim.

"Yahya said from Malik from Ibn Shihab from Urwa ibn az-Zubayr that A'isha, the wife of the Prophet, may Allah bless him and grant him peace, said, "Utba ibn Abi Waqqas disclosed to his brother, Sad ibn Abi Waqqas, that he was the father of the son of the slave-girl of Zama, and made him promise to look after him (after his death). In the year of the conquest, Sad took him and said, 'He is the son of my brother. He covenanted with me about him.' Abd ibn Zama stood up and said, 'He is my brother and the son of my father's slave-girl. He was born on his bed.' They went to the Messenger of Allah, may Allah bless him and grant him peace. Sad said, 'Messenger of Allah! He is the son of my brother; he made a covenant with me about him.' Abd ibn Zama said, 'He is my brother and the son of my father's slave-girl and was born on my father's bed.' The Messenger of Allah, may Allah bless him and grant him peace, said, 'He is yours, Abd ibn Zama.' Then the Messenger of Allah, may Allah bless him and grant him peace, said, 'A child belongs to the household (where he was born) and the adulterer is stoned.' Then he told Sawda bint Zama, 'Veil yourself from him,' since he saw in him a resemblance to Utba ibn Abi Waqqas." A'isha added, "He did not see her until he met Allah, the Mighty, and the Majestic!".

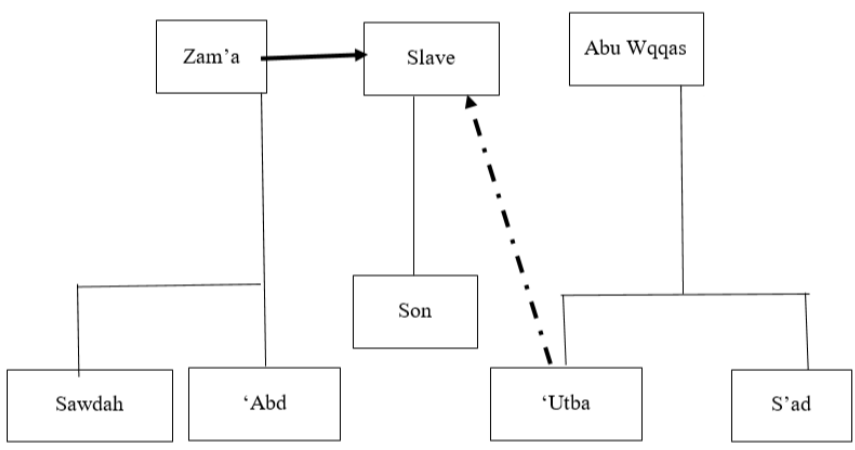

Figure 1. Disputing parties and the disputed son

${ }^{8}$ Abdul Baqi Fuwad. "Al-Lu-lu-wal-Marjan: A Collection of Agreed upon Ahadith from Al-Bukhari and Muslim: Volumes One and Two." (1995). 
The lines in Figure 1 indicate an undisputed blood relationship, and the arrow indicates licit sex, while the boldly dotted arrow indicates illicit intercourse.

It has been reported that Arabs in the pre-Islamic era were fond of compelling slave-girls to engage in prostitution and they used to keep the illegitimate children. ${ }^{9}$ The children used to be attributed to their biological fathers whenever they were claimed in the same manner they were accustomed to in a legitimate marriage. ${ }^{10}$ If the child happened to be claimed by two or more people, they used to resort to physiognomists as their arbiter. ${ }^{11}$

The prevalent tradition during that time had caused 'Utbah to instruct his brother (Sa' ad) to claim the child that he thought to be his. During the year of the conquest (of Makkah), Sa'ad made an attempt to claim the child begotten by Zam'ah's slave-girl. However, 'Abdullah ibn Zam'ah raised an objection against the claim and the dispute was brought to the awareness of the Prophet ((s.a.w)). Having listened to the disputing parties, the Prophet ((s.a.w).) invalidated the widespread custom of Arab before the advent of Islam and he attributed the child to Zam'ah. ${ }^{12}$

This is the Prophetic verdict during the conflict between the owner of firash and the fornicator where he gave preference to a legitimate marriage even though there was a striking resemblance between the claimed child and the fornicator. Since that time, the evidence based on a legal marriage has become incontrovertible which cannot be refuted with unconvincing proofs. The verdict has been unanimously agreed upon by Muslim jurists. ${ }^{13}$ However, Muslim jurists have different views on the

\footnotetext{
${ }^{9}$ Ismail Ibn Kathir, Tafsīr al-Qur'ān, (Riyadh: Dar al-Taibah li al-Nashr wa alTawzī', 1999), vol. 2, 42

${ }^{10}$ Bin Muhamad, Mohd Munzil, Ahmad Azam Mohd Shariff, Ramalinggam Rajamanickam, Mazupi Abdul Rahman, Anowar Zahid, and Noorfajri Ismail. "Qarinah: Admissibility of Circumstantial Evidence in Hudud and Qisas Cases." Mediterranean Journal of Social Sciences 6, no. 2 (2015): 141.

${ }^{11}$ Muhammad \& Umar Salihu. "An Analysis of the Means of Proof under Islamic Law." Phd Diss., Ahmadu Bello University, Zaria, 2011, 135.

12 Ibn al-Mulaqqin, al-'Ilam bi Fawaid 'Umdat al-Ahkām, (Riyadh: Dar al'Asimah, 1997), vol.8, 467

${ }^{13}$ Sujimon, M. S. "Istilhāq and Its Role in Islamic Law." Arab Law Quarterly 18, no. 2 (2003): 117-143.
} 
attribution of the illegitimate child to the biological father when the child's mother is unmarried. ${ }^{14}$

Having meticulously studied the classical books of Islamic law, the scholars' opinions on the subject matter can be categorized into three different Schools, which shall be discussed. ${ }^{15}$ The majority of Muslim jurists are of the opinion that any child born out of wedlock cannot be attributed to his biological father, and no familial affiliation should be established between them, though they all agree with attributing the child to his mother. The majority scholars of Hanafis, Malikis, with exception of Ibn Qasim, Shafi'is, Hanbalis, and Zāhiris, have ventured this opinion. ${ }^{16}$ On the contrary, some scholars are of the opinion that it is allowed to attribute a child born out of wedlock to his putative father when he claims his paternity, provided the woman that gave birth to the child is unmarried or in another word, under firāsh. This opinion is held by some jurists among Tabi'un and it was reported that al-Hasan al-Bașri said about a man who committed illicit sexual intercourse with a woman and claimed the child begotten from the act that "he (the man who commited zina) should be lashed and the child be attributed to him". ${ }^{17}$

Similarly, Ishâq ibn Rahwayyah used to issue a verdict over a child born out of wedlock that the child should be attributed to his putative father when paternity is claimed as long as his mother is unmarried. The same opinion was reported from 'Urwah ibn al-Zubair and Sulaiman ibn Yasâr on a condition that the child is not claimed by any legitimate father or born by a married woman. It was reported that Ibrahim al-Nakha'iy

${ }^{14}$ Ibn 'Abd al-Barr, Al-istidhkār al-Jāmiu li Fuqahāh al-Amsār, (Beirut: Dar alKutub al-Ilmiyyah, 2000), vol. 7, 172.

15 Ahmad Yahya Ibn al-Murtadha, al-Bahr al-Zakhār, (Beirut: Mus-sat alRisalah, 1975), vol. 4, 141.

16 Abdullah ibn Ahmad Ibn Qudamah, al-Mughni, (Beirut: Dar alKitab alArabiy, 1985), vol.7, 477.

, Ibn Qayyim al-Jawziyyah, Zād al-Ma'ād, vol. 5, 381. vol. 7, 129. Al-Kasāni Abu al-'Ala', Badāi 'u al-Sanāi 'u fi tartīb al-Sharai'u, (Beirut: Dar al-Kutub al'Ilmiyyah, 1976), vol. 6, 242

17 This was narrated by al-Darimiy from Sulaymn ibn Yasir who said that any man who claims a child begotten out of wedlock would be attributed to him and would inherit him as long as the child is not claimed by another person and the woman is not married. Bukair said that he asked 'Urwah about the verdict and replied in the same vein to Sulayman ibn Yasir. Sunan al-Darimiy. 
used to say that the fornicator should not be denied of paternity of his child after being punished. Abu Hanifah said that if the fornicator marries a woman even a day before giving birth, the child would be attributed to him, but affiliation would not be established if he fails to marry her. AlQādi Abu Ya'la and some jurists of the Hanafi school of law are of the opinion that the affiliation of the illegitimate child depends on the verdict of the judge. ${ }^{18}$

Ibn Qāsim is at a variance with the predominant ruling of the scholars of Malikis. He asserted that when an inhabitant of dār al-harb embraces Islam and claims their children born out of illicit acts before Islam, ${ }^{19}$ the children are to be affiliated to him on the condition that there are no other legitimate claimants. Otherwise the children is to be attributed to the legitimate husband of the woman. ${ }^{20}$ Although he refuted hearing such verdict from Imam Maliki. He only substantiated his view with what had been reported from 'Umar ibn al-Khattab. Among the Malikis who are of the opinion that the illegitimate child can be attributed to his biological father is Ibn Kinānah as reported by al-Bājî in his commentary on Al-Muwatța. ${ }^{21}$

Among other scholars with this opinion are Ibn Taymiyyah and his famous disciple, Ibn Qayyim, as he gives precedence to the opinion over the opponents' views in several places of his Fatāwa. ${ }^{22}$

The complex cases of illegitimate children and the juristic conundrum have drawn some contemporary scholars to legal discourse by revisiting the classical books of the past jurists with their intellectual contributions. Among them are, Muhammad Rashid Ridha, ${ }^{23}$ Ibn

\footnotetext{
18،Ali ibn Sulayman Al-Mardāwî, al-Insāffi M'arifat al-Rāhjih mina al-Khilāf, (Beirut: Dar Ihyai al-Turāth), vol. 9, 269.

19 Malik ibn Anas, al-Mudawwanat al-Kubra, (Beirut: Dar al-Kutub al'ilmiyyah, 2008), vol. 3, 340.

${ }^{20}$ Muhammad Abu Abdullah, Mawāhib al-Jalīl Sharh Mukhtâ̂ar al-Khalīl, (Oman, Dar al-Ridhwān, 2010), vol. 7,

21 Al-Bājî Sulayman Ibn Khalaf, al-Muntaqā Sharh al-Muwața' (Cairo: Matb'ah al-Sa'ādah, 2000), vol. 6, 8 .

${ }^{22}$ Muhammad Ibn AbuBakr Ibn al-Qayyim al-Jawziyyah, Zād al-Mi'ad fi Hadyi Khai al'Ibād, (Beirut, Muassasat al-Risalah, 1994), vol.5, 426.

${ }^{23}$ Muhammad Rashid Ridah, Tafsir al-Manar, (Cairo: al-Haihah al-Misriyyah lil Kuttāb, 1988), vol4, 382
} 
'Uthaimin, 'Abdul-Rahman bn S'adi, 'Abdul 'Azeez Ibn Fawzan, 25 Sa'duddeen al-Hilāli, ${ }^{26}$ Said Ahmad ${ }^{27}$ and many more.

\section{Argument against Legitimation of the Illegitimate Child}

The following are the proofs provided by scholars who are of the opinion that the legitimation of children born out of wedlock is impermissible.

The majority of scholars claim that the Prophet ((s.a.w).) has absolutely invalidated any familial relationship between the illegitimate child and the fornicator in his statement, "wa lil 'âhir al-hajar" which encompasses every situation, whether a child is born by a married or unmarried woman. ${ }^{28}$

Al-Jassas said that the statement necessarily conveys two meanings, one of which is attributing a child to his legitimate father and the second is that whoever does not own firash (wife), has no legal right to paternity. In addition, the word "al-firāsh" is used in a generic term with the inclusion of definite article (alif and lâm) that makes filiation of any child within the confine of the marriage contract. Therefore, no child is to be attributed to anyone that does not have a wife. ${ }^{29}$

Al-Kâsani has adopted three different approaches in interpreting the hadith:

${ }^{24}$ Muhammad Sailh Ibn 'Uthaymeen, al-Sharh al-Mumti'u 'Ala Zād alMustanqi' (al-Damam, Dar al-Nashr Dar-Ibn al-Jawzi, 2001), vol 12, 127.

25 'Abdul 'Azîz Ibn Fawzan, Hal Yarith Walad al-Zina, accessed October 25, 2016. https://www.youtube.com/watch?v=aP0emyZQjms/.

26 Sa'duddin al-Hilāli, Ikhtilāf al-Fiqhi fi Tansīb Ibn al-Zina /https://www.youtube.com/watch?v=YIBHAaYQJ8w/ accessed October 25, 2016.

${ }^{27}$ Sa'duddin al-Hilāli, al-Basmat al-Wirāthiyyah wa 'Alāqatuha al-Shar'iyyah, (Kuwait: Kuwait University, 1st edition), 356.

${ }^{28}$ Serrano, Delfina. "Paternity and Filiation According to the Jurists of AlAndalus: Legal Doctrines on Transgression of the Islamic Social Order." Imago Temporis: Medium Aevum (2013): 59-75.

${ }^{29}$ Al-Jassa Abubakar, Ahkam al-Qur'an, (Beirut: Dar al-Kutub al-'Ilmiyyah, 1994), vol. 3, 396. 
i. the Prophet (s.a.w).) expressed the statement in position of division by attributing a child to the owner of bed (the husband) and for the fornicator is to be stoned, i.e., "the child belongs to the owner of the bed, and it is forbidden to be attributed to the adulterer".

ii. He established paternity for the owner of firāsh (wife's husband and invalidated the right of ownership from the fornicator simultaneously.

iii. Lastly, the Prophet (s.a.w).) exclusively attributed all kinds of children to the owner of the bed because if a child's family is attributed to people without legitimate wives, all children would not be attributed to their legitimate father. ${ }^{30}$

There is no doubt that this contravenes the legal injunction. Therefore, if a child is born out of illicit sexual intercourse and the child is claimed by his putative father, he would be denied of paternity, though the child would be attributed to his mother by virtue of birth. ${ }^{31}$

The above evidence has been disproved that the hadith is specific to a situation where the owner of firäsh is involved, and where there is no dispute in claiming the child. In this situation, the child should be attributed to the claimant. Ibn Taymiyyah affirmed that Umar Ibn Khattab would not have affiliated children born during pre-Islamic era to whoever claimed them with his awareness of the verdict of the Prophet (s.a.w). between Zam'ah and Sa'ad except that he had understood that the judgment was circumstantial which was the claim made by the owner of firāsh. ${ }^{32}$

The opponents of legitimation have substantiated their opinion with the hadith narrated from Ibn 'Abbas. The Prophet (s.a.w). said:

"There is no prostitution in Islam. If anyone practised prostitution in pre-Islamic times, the child will be attributed to the master (of the slave-

${ }^{30}$ Abubakr ibn Mas'ûd Al-Kasâni, Badāi'u al-Sanāi'u fi tartīb al-Sharai'u, (Beirut: Dar al-Kutub al-'Ilmiyyah, 1976), vol. 6, 242.

${ }^{31}$ Ibid

${ }^{32}$ Ahmad ibn 'Abd al-Halīm Ibn Taymiyyah, Majmu'u Fatawah, (Maktabah Ibn Taymiyyah, reviewed by Ibn Qasim al-Najdi), vol. 32, 112. 27 
woman). He who claims his child without a valid marriage or ownership will neither inherit nor be inherited". 33

Al-musâ' $\hat{a} t$ is the act of prostitution practised by slave-girls to pay their masters in the pre-Islamic era. The Prophet (s.a.w) invalidated the practice without attributing the children born out of the act, and he did not differentiate between the child born with or without fir $\bar{s} h^{34}$

The above evidence has been criticized by other scholars that the chain of narration of the hadith is questionable due to the mentioning of an anonymous person. Therefore, it cannot be used as proof. ${ }^{35}$

The opponents of legitimation of the illegitimate child have also strengthened their argument with hadith reported by 'Amr bn Shu'aib:

"The Prophet (s.a.w). decided regarding one who was treated as a member of a family after the death of his father, to whom he was attributed when the heirs said he was one of them, that if he was the child of a slave-woman whom the father owned when he had intercourse with her, he was included among those who sought his inclusion, but received none of the inheritance which was previously divided; he, however, received his portion of the inheritance which had not already been divided; but if the father to whom he was attributed had disowned him, he was not joined to the heirs. If he was a child of a slave-woman whom the father did not possess or of a free woman with whom he had illicit intercourse, he was not joined to the heirs and did not inherit even if the one to whom he was attributed is the one who claimed paternity, since he was a child of fornication whether his mother was free or a slave". 36

The Prophet (s.a.w) issued a verdict that if a child is claimed by heirs after the demise of his father to whom he was attributed, the situation would be treated in two different ways. Firstly, a child might have been born by a slave-woman who had been consummated by her master. The child in this situation is to be attributed to the claimant and be treated as a

33 Sulaiman ibn al-Ash'ath al-Sajistāni, Sunan Abi Dawud, (Beirut: Dar alKitaab al-'Arabi, 1987), vol. 2, 246.

${ }^{34}$ Muhammad Ibn Muflih al-Mardāwi, al-Furû' (Cairo: Mu'assasah al-Risālah, 2003), vol. 5, 404.

${ }^{35}$ Ibn Qayyim al-Jawziyyah, Zād al-Ma'ād, vol. 5, 427. See also Nail al-Awțār, vol. 6, 184.

36 Ibid. 
member of the family as explained by the Prophet (s.a.w) regarding inheritance. ${ }^{37}$ Secondly, a child might have been born by a slave-woman from her master but his father to whom he was attributed used to disclaim him before his death. In this situation, the child is not to be attributed to him even if the heirs claim him to be legitimate for the fact that the child has been disclaimed by the root (father).

Moreover, the Prophet (s.a.w). explained the ruling of a child born out of wedlock in the hadith that, "If he was a child of a slave-woman whom the father did not possess or of a free woman with whom he had illicit intercourse, he was not joined to the heirs. He did not inherit even if the one to whom he was attributed to is the one who claimed paternity. This is because he was a product of fornication whether his mother was free or a slave". So the Prophet (s.a.w). attributed the illegitimate child to his mother be it free or slave-woman and invalidated his filiation to his putative father (fornicator) without differentiating between the child born through an illicit relationship or born through an illegal sexual intercourse. $^{38}$

The above proof has also been rebutted that the chain of narration of the hadith cited contains Muhammad Ibn al-Makhûlîn, which makes it unjustifiably untenable and weak. The scholars who disagree with legitimising the child born out of wedlock further buttress their perspective with hadith reported by 'Amr ibn Shu'aib that the Prophet ((s.a.w).) said:

37 Ahmad S'ad 'Ali, "al-Takhrīj al-Fiqhī li Tansībi Awlād al-Zinā wa alIghtișāb", Majallah Dar al-Iftāi al-Mișriyyah, (2012), 7.

${ }^{38}$ Ibn al-Muflih Ibrahim Muhammad, al-Mubdi'I fi Sharh al-Miqni'I (Beirut: alMaktab al-Islamiy, 1979),

${ }^{39} \mathrm{He}$ is Abu Yahyā Muhammad ibn Rashid famously known as al-Makhuli. The scholars of hadith differ about his status in the field of hadith. Among them who found him versed and experienced in hadith like Imam Ahmad and Yahya Ibn ma'een. However, some other scholars considered to be inexperienced. AlNasai has been reported to have considered him weak, and Ibn Hibban said that he was known for asceticism not for the science of hadith. See Al-Khatị̂b alBaghdādī, Tārīkh al- Baghdād, (Beirut: Dar al-Kutub al-'Ilmiyyah, 1417), 389. 
"Whoever commits adultery with a slave woman or a free woman, his child is illegitimate, and he cannot inherit from him or be inherited from (i.e., this child cannot inherit from him)."

The basis of the proof is that the Prophet's verdict prohibits affiliating illegitimate child to the fornicator without considering whether the woman is owned by a husband or not by the word "whoever" that gives no room for any probability. The chain of narration of the hadith used has been disproved due to ibn Luhai' ah that makes it very weak. ${ }^{41}$

The majority scholars logically substantiated their view that if the fornicator is allowed to claim his child, it might consequently lead to intermixing of lineage. This is because the mother of the illegitimate child might have had illicit sexual intercourse with another man and the child's intermixing of lineage can be sorted out with advanced medical technology that can identify the real biological father. It is believed that preventing the fornicator from claiming his putative child is a means of imposing punishment on him and a deterrent to other would-be offenders to avoid illicit acts.

These arguments may be refuted by refering to the changing circumstances and what could be seen as a punishment in the past is no longer effective. Attributing illegitimate children to their putative parents has become a stiff penalty in several societies because of parental responsibilities that must be burdened by them. ${ }^{42}$ Besides, most biological fathers of children born out of wedlock in most Muslim countries usually detest being affiliated to those innocent children. That is why the number of abandoned children are drastically increasing. ${ }^{43}$

\footnotetext{
${ }^{40}$ Abu Daud, Sulaiman ibn al-'Ash'ash, Sunan Abi Daud, (Beirut, Dar al-Kutub al-'Arabi, 1979), vol. 2247.

41 In the chain of narration of the hadith is Abu Luhaihah that makes it questionable. See Abu Abdullah al-Dhabi Shamshud-Deen, Mīzān al- 'Itidāl $f i$ Naqd al-Rijāl, (Beirut: Dar al-M'arifah li al-Tab'i wa al-Nashr: 1963), vol. 2, 476.

${ }^{42}$ S'aduddeen Hilali, al-Basmat al-Wirāthiyyah wa 'Alāqatuha al-Shar'iyyah, (Kuwait: Kuwait University, 1st edition), 356.

${ }^{43}$ Qanv̄n Jadīd fi al-Jazair li Ithbāt Nasab al-Aṭ̂āf ghayr al-Shar'iyyīn < https://alqabas.com/301628/> accessed 3th November, 2018.
} 


\section{Argument in Favour of Legitimating Illegitimate Children}

The following are the proofs provided by scholars who hold the opinion that children born out of wedlock can be legitimized.

The proponents of this view have substantiated their argument with proofs from the Quran, Sunnah and analogical reasoning. As for the Quranic evidence, Allah (s.w.t) says to the effect:

"Every soul will reap the fruits of its own deeds; no bearer of burdens shall bear the burden of another. Ultimately you will return to your Rabb, and He will resolve for you your disputes."

It is deduced from the verse that attributing an illegitimate child to his putative father is when his mother is unwed is an intense interest in preserving the child's lineage. Besides, failure in carrying out this interest would be consequently detrimental to the life of the innocent child. Therefore, denying the child of paternity is tantamount to injustice that is inconsistent with the above verse and the objective of the Islamic law at large. ${ }^{45}$

From the Sunnah of the Prophet ((s.a.w)), It was narrated that 'Aishah (R.A) said:

"Sa'ad bin Abi Waqqas and 'Abd bin Zam'ah disputed concerning a son of Zam'ah. Sa'd said: 'My brother 'Utbah urged me, if I came to Makkah: Look for the son of the slave woman of Zam'ah, for he is my son.' 'Abd bin Zam'ah said: 'He is the son of my father's slave woman who was born on my father's bed.' The Messenger of Allah ((s.a.w)) saw that he resembled 'Utbah, but he said: "The child is the bed's. Veil yourself from him, O Sawdah." 46

It is deduced from the hadith that the Prophet's consideration of resemblance of the fornicator in his judgment by asking Sawdah to veil herself from the child is a clear proof. Had the resemblance not been considered, the Prophet ((s.a.w).) would not have asked her to do so. Ibn

${ }^{44}$ Surah al-An'am, (6:164), Translation by Abdullah Yusuf Ali

${ }^{45}$ Sa'd Ibn Turki, Ahkam Al-Aulad Al-Natijin An Al-Zina, a Paper Presented At 20th Conference Of International Islamic Fiqh Academy, 25-29 December, $2010,37$.

${ }^{46}$ Muhammad ibn Futuh al-Humaidi, al-Jam'u baina al-Sahīhain al-Bukhari wa Muslim, (Beirut: Dar Ibn Hazm, 2002), vol. 4, 64. 
Hajar said that the Hanafis viewed that how Sawdah could be instructed from veiling herself from the child if he was truely her brother. In fact, in some parts of the narration, the Prophet ((s.a.w).) said, 'veil you from him, O Sawdah, for he is not a brother of yours', although, the scholars are at variance about the authenticity of this additional statement. ${ }^{47}$

The majority of scholars who oppose this opinion have replied that the additional text must be given plausible interpretations, though they disagree on how it should be interpreted. Ibn Hazm argued that the instruction of Sawdah to veil herself from the child does not violate the principle of 'the child belongs to the bed's'. Moreover, veiling the brother from his sister does not necessarily render familial relationship null and void this is because it is not obligatory for a brother to see his sister, what they are obliged to do is to maintain the bonds of kinship. ${ }^{48}$

Besides, Sawdah (R.A) was never instructed to cut the bonds kinship with the child. It is also believed that the Prophet's instruction could have been a precautionary measure, having seen a marked resemblance between 'Atabah and the child. This has been substantiated by AlKhattab when he said that the instruction indicates the privileged status for the wives of the Prophet ((s.a.w)). Al-Qurtubī after affirming the possibility of adopting precautionary measure in Sawdah's veiling, argued that there is a strong probability that the instruction was issued to show how important the use of hijab was for the wives of the Prophet $(($ s.a.w $))$. In the same way he permitted them not to see a blind man, ${ }^{49}$ 'Are you two blind such that you cannot see him?', ${ }^{50}$ and his instruction to Fatimah Bint Qais, 'Spend 'Iddah period in the house of your cousin,

\footnotetext{
${ }^{47}$ S'aduddin Hilali, 359

${ }^{48}$ Muhammad Ali Ibn Hazm Abu, al-Muhallah, (Beirut, Dar al-Fikr, 1984), vol. 9491.

${ }^{49}$ Muhammad Ibn Ahmad Al-Qurtubi, al-Jamiu' li Ahkām al-Qur'ān, (Riyadh, Dar 'Alam al-Kutub, 2003), vol. 9, 4.

${ }^{50}$ Narrated Nabhan the freed slave of Umm Salamah to Ibn Shihab, that Umm Salamah narrated to him, that she and Maimunah were with the Messenger of Allah ((s.a.w)), she said: "So when we were with him, Ibn Umm Maktum came, and he entered upon him, and that was after veiling had been ordered for us. Therefore, the Messenger of Allah ((s.a.w)) said, 'Veil yourselves from him.' So I said: 'O Messenger of Allah! Is he not blind such that he cannot see us or recognize us?' So the Messenger of Allah ((s.a.w).) said: 'Are you two blind such that you cannot see him?""
} 
Ibn Umm Maktum. He is blind and you can put off your garment in his presence'. ${ }^{51}$

The proponents of the legitimation of the illegitimate child further substantiate their opinion with hadith of Juraij recorded by al-Bukhari and Muslim:

“Allah's Messenger ((s.a.w)) said, "There was an Israeli man called Juraij, while he was praying, his mother came and called him, but he did not respond to her call. He said (to himself) whether he should continue the prayer or reply to his mother. She came to him the second time and called him and said, "O Allah! Do not let him die until he sees the faces of prostitutes." Juraij used to live in a hermitage. A woman said that she would entice Juraij, so she went to him and presented herself (for an evil act) but he refused. She then went to a shepherd and allowed him to commit an illegal sexual intercourse with her and later she gave birth to a boy. She alleged that the baby was from Juraij. The people went to Juraij and broke down his hermitage, pulled him out of it and abused him. He performed ablution and offered the prayer, then he went to the male (baby) and asked him; "O boy! Who is your father?" The baby replied that his father was the shepherd. The people said that they would build for him a hermitage of gold but Juraij asked them to make it of mud only." ${ }^{52}$

Juraij asked the child whom was born out of fornication with the word, "who is your father?" and he miraculously replied "the shepherd". It is argued that the statement made by the child was by Allah's Almighty power, which could involve neither lie nor distortion. Therefore, it is allowed to affiliate illegitimate children to their biological father. $^{53}$

Al-Qurtubī explained that the Prophet (s.a.w) narrated that Juraij attributed a child born out of fornication to the fornicator with an unusual confirmation from Allah (s.w.t.) through the baby's attestation. The Prophet (s.a.w) in the same vein reported the miracle of Juraij in the term

${ }^{51}$ S'ad Ibn Turki, Ahkam Al-Aulad Al-Natijin An Al-Zina, a Paper Presented At 20th Conference Of International Islamic Fiqh Academy, 25-29 December, $2010,37$.

${ }^{52}$ Muhammad ibn Futuh al-Humaidi, al-Jam'u baina al-Sahīhain al-Bukhari wa Muslim, (Beirut: Dar Ibn Hazm, 2002), vol. 3, 129.

${ }^{53}$ Muhammad ibn Abu Bakr Ibn al-Qayyim al-Jawziyyah, Zad al-Mi'ad fi Hadyi Khai al'Ibad, (Beirut, Muassasat al-Risalah, 1994), vol.5, 426. 
of laudation that made the child's attribution be authentically legitimate with Allah's confirmation. ${ }^{54}$

This argument has been refuted by the majority of scholars that the ruling deduced from the hadith is a law revealed prior to the advent of Islam (sharhu man qablana). Perhaps, the statement "who is your father" asked by Juraij might have been out of inquiry about the fornicator who was regarded as father figuratively. Al-Nawawi responded that attributing the illegitimate child to their putative father might be permissible in their law. ${ }^{55}$

Additionally, some scholars are of the opinion that the illegitimate child can be legitimated and attributed to his putative father on condition that he marries the woman he committed fornication with during gestation period, but if he fails to marry her until she gives birth to the baby, the child shall not be attributed to him. This opinion is held by Ibn 'Abbas, Abu Hanifah and Muhammad (his disciple), based on this is fatwa in their School of law. It has been reported that Ibn 'Abbas was once asked about a man guilty of fornication with a woman and whether marrying her or not. He (Ibn 'Abbas) said that it is from fornication to a marriage contract. He said in another narration from him that the man could marry her if they both repent. ${ }^{56}$

Legitimation of Ziyād was made by Mu'āwiyah Ibn 'Abu Sufyān by attributing him to his father and consequently became his brother. Ziyād used to be known as Ibn Abīh as acknowledged by Mu'āwiyah when a man witnessed that Abu Sufyān had an illicit sexual affair with Summayah (Ziyād's mother) during the pre-Islamic era and give, an affair that produced Ziyād. Therefore, he officially declared Ziyād to be the son of Abu Sufyān, and his name was changed in official records

\footnotetext{
${ }^{54}$ Muhammad Ibn Ahmad Al-Qurtubi, al-Jamiu' li Ahkām al-Qur'ān, (Riyadh, Dar 'Alam al-Kutub, 2003), vol. 9, 4.

55 ibid

${ }^{56}$ See Ali Muhammad, al-Hāwì al-Kabìr fi Fiqh Madhab al-Shāfi' $i$, (Beirut: Dar al-Kutub alllmiyyah, 1999), vol. 8, 162. Al-Mughnī li Ibn Qudāmā, vol. 8, 129. Zād al-Mi'ād Ibn Qayyim, vol. 5, 425, Al-Furû' li Ibn Muflih, vol. 5, 403.
} 
from Ziyād Ibn Abīh to Ziyād Ibn Abu Sufyān. He was also made a beneficiary of Abu Sufyān's inheritance as his son. ${ }^{57}$

Legitimation of Ziyād was carried out while numerous numbers of companions of the Prophet ((s.a.w)) were alive without any public condemnation. Besides, it is implausible for a companion like Mu'āwiyah to make the impermissible permissible. The assumption that Mu'âwiyah prompted the legitimation because of Ziyād's considerable acumen, as claimed by some scholars, would not have been carried out if legitimation had no basis in Islamic law. It would have been better if what he did was referred to as ijtihad. Besides, some notable scholars of Islam referred to Ziyād as Ibn Abu Sufyān, like Imam Bukhari and Imam Malik and many more. ${ }^{58}$

Lastly, it should be known that a child born out of wedlock biologically belongs to his putative father by predestination. Moreover, there is no clear proof that disallows legitimizing him. Ibn 'Uthaimeen asserted that a child born out of wedlock should be attributed to his putative father when he (illegitimate child) is claimed because predestination cannot be contradicted with the divine rule (hukm shar'i). How could predestination be ignored when it is obvious that the child was created from his spermatozoon. Predestination can only be overruled by divine rule with a clear proof. ${ }^{59}$ Failure to differentiate between predestination and divine rule (al-hukm al-kawni and al-hukm shar'i) has probably made the majority of scholars to reject the concept of legitimation. ${ }^{60} \mathrm{Ibn}$ 'Uthaimeen has affirmed in another book that the

${ }^{57}$ Ibn al- Kathīr, "Al-Bidayah wa al-Nihayah (The Beginning and the End)." (Lebanon, Dar-Ihya al-Turath, 1989), vol. 8, 31.

${ }^{58}$ Ali ibn muhammad Ibn Athir, al-Kamil fi al-Tarikh, (Beirut: Dar al-Kutub al'Arabi, 1989), vol.1, 331.

${ }^{59}$ Muhammad Sailh Ibn 'Uthaymeen, Fathu, Dhil al-Jalal, (Cairo: al-Maktaba al-Islamiyyah li al-nashr wa al-Tawzi', 2006), vol. 12, 318

${ }^{60} \mathrm{Al}$-hukm al-kawni is what has been predestined to occur and would inevitably happen. This comprises both what Allah is pleased and what He is not pleased with something might be predestined by Allah without being pleased with it like, polytheism, adultery, and other vices. Conversely, According to legal theorists, hukm shar'i is the communication from Allah, the Exalted, relating to the acts of the subjects by way of a demand or an option or a declaration. Al-hukm shar' $i$ may or not occur. For instance, if prayer (salat) is made compulsory on His servants and they may or not observe it. 
opinion that allows children born out of wedlock to be legitimated and attributed to their putative father when he is claimed is more acceptable to both common sense and the objective of Islamic law. ${ }^{61}$

The proponents of legitimation analogically compare the child born out of wedlock with a child disclaimed through imprecation (li'an). It is said if the child disavowed could be reclaimed by his father after his acknowledgement, it should be also allowed for a putative father to claim his child.

The opponents reply that the analogy is fallacious due to the essential differences between the children disclaimed by imprecation and the child born out of wedlock for the fact that the former is automatically legitimate. Besides, the issue of imprecation is completely irrelevant. On the contrary, the child born out of wedlock is automatically illegitimate. ${ }^{62}$

The proponents also compare the putative father with the mother of a child born out of wedlock in their involvement in illicit acts; nevertheless, the child is automatically attributed to his mother. This analogy has been established by Ibn Qayyim. He argued that the mother is involved in fornication with her partner and the child is allowed to be attributed to her and her relatives with legal rights of inheritance from them; why should the putative father be denied of attribution when the mother is unmarried and the child is not claimed by any other person? This is a clear analogy as he claims. ${ }^{63}$

However, Al-Sarakhsī said that a woman could have been consummated by different men who could lead to the ambiguous attribution of the child to whom may not be the real father and this ambiguity does not arise in the case of women. Therefore, it is not allowed to attribute such a child to any of the men. Al-Kâsâni has also replied that the legitimacy of a child is established through the principle

61 Muhammad Sailh Ibn 'Uthaymeen, al-Sharh al-Mumti'u 'Ala Zad alMustanqi' (al-Damam, Dar al-Nashr Dar-Ibn al-Jawzi, 2001), vol 12, 127.

${ }^{62}$ Nurudeen Mukhtar al-Khami, Genealogy of a child born out of wedlock, a paper presented at $20^{\text {th }}$ seminar of International Islamic Fiqh Academy, Jeddah, on the $29^{\text {th }}$ December, 2010.

${ }^{63}$ Ibn al-Qayyim, Zād al-Mi'ād Fi Hadyi Khairil al-'Ibād, (Mus-sasat alRisalah, 1986), vol.5, 429. 
of 'the child belongs to the bed's'; and attribution of the child to his mother is established through birth, the judgment should be different. ${ }^{64}$

"Malik related to me from Yahya ibn Said from Sulayman ibn Yasar that Umar ibn al-Khattab used to attach the children of the Jahiliyyah to whoever claimed them in Islam. Two men came and each of them claimed a woman's child. Umar ibn al-Khattab summoned a person who scrutinized features and he looked at them. The scrutinizer said, "They both share in him." Umar ibn al-Khattab hit him with a whip. Then he summoned the woman, and said, "Tell me your tale." She said, "It was this one (indicating one of the two men) who used to come to me while I was with my people's camels. He did not leave me until he thought and I thought that I was pregnant. Then he left me, and blood flowed from me, and this other one took his place. I do not know from which of them the child is." The scrutinizer said, "Allah is greater." Umar said to the child, "Go to whichever of them you wish." ${ }^{65}$

The point here is that Umar used to attribute the children born out of illicit act in the pre-Islamic era to whoever claimed them after Islam. When a Muslim came and claimed to be the putative father of a child born out of fornication who did not have a legitimate father in the preIslamic period, Umar would accept his claim and attribute the child to him as can be understood from the hadith. In another narration,

"Some female-girls of the pre-Islamic era were brought to Umar, and he ordered their children to attribute to their biological fathers and that they should not be enslaved". 66

This verdict issued by Umar because those children were born by unmarried women who belonged not to any legitimate husbands. So Umar attributed them to their biological fathers pursuant to the judgment of the Prophet ((s.a.w)) between Sa'ad and Abdullah bn Zam'ah in the hadith previously mentioned; "the child belongs to the household".

The majority of scholars responded to the argument that the Umar judgment was restricted to children born before Islam where there was no legitimate household to claim them because the verdict on prostitution

\footnotetext{
${ }^{64}$ Sufyan Umar, 238

65 Imam Malik Ibn Anas, Kitab al-Muwatta', (Cairo: Dar Ihya al-Kutab al'Arabiyyah, 1351), no. 1370 (1986): 244- 45. Book 36, Hadith 2.

${ }^{66}$ Al-Tahāwi, Sharhu Mushkil al-Athār, (Beirut: Muassat al-Risālah, 1987), vol.11, 16.
} 
was supposed to be more lenient than when Islam the illicit act has become prohibited. Therefore, the verdict issued that time is no longer applicable after the widespread of Islam. ${ }^{67}$

It is worth mentioning that scholars differ over marrying a woman with a blemish of adultery. The Malikis and Hanbalis hold the view that any woman caught of illicit sex should not be married whether the man who wants to marry her is the co-adultery or another person except after assuring of the vacation of her womb or deliverance of her fetus. The view is based on the reasoning that vacation of the womb is necessary for avoiding mixing up of permissible semen with impermissible. ${ }^{68}$ However, scholars of the Shafi'i School held that the permissibility of a woman caught in adultery to be married either by a man with whom she committed or another person with the permissibility of consummation whether she is pregnant or not. This is on the basis that the semen out of fornication is valueless. Therefore, an illicit act cannot be an impediment to carrying out what is legally permitted. ${ }^{69}$

It has been reported that Ibn Abbas used to comment regarding a person who married a woman he had fornicated with, his beginning was fornication and the ending was marriage. His example is like that of a person who steals from a garden and then goes to the owner to buy what he stole. What he stole was haram and what he bought is halal. ${ }^{70}$ This

${ }^{67} \mathrm{Ibn}$ 'Abd al-Barr, Al-istidhkār al-Jāmiu li Fuqahāh al-Amsārr, (Beirut: Dar alKutub al-Ilmiyyah, 2000), vol. 7, 172.

${ }^{68}$ This view is also held by Abu Yusuf of Hanafiyyah, though he exempted a situation where the person who wants marry the woman is her co-adulterer and the woman is free from pregnancy. In this case, it is permissible to the woman. See Muhammad Ameen ibn 'Abidīn, Hāshiyah Ibn 'Abidīn, (Beirut: Dar alKutub al-'Ilmiyyah: 1980), vol. 2, 292, Ahmad Ibn Ghanim, al-Fawāqihu alDawāni, (Beirut: Dar al-Fikr, 1995), vol.2, 34, Muhammad Al-Dusûqi 'Arafat, Hashiyat al-Dusûqī 'alā al-Sharh al-Kabir, (Cairo: Matba'at al-Sabih, 1934), vol.2, 471.

${ }^{69}$ Ibrahim ibn 'Ali al-Shīrāzī, Al-Muddhab, (Cairo: Dar al-Qalam, 1959), vol.2, 43.

${ }^{70}$ Muhammad Ibn Hassan Al-Shaybāni, al-Hujjah 'alā Ahl al-Madinah, (Beirut: 'Alam al-Kutub, 1936), vol. 3, 393. See also Y'aqûb Ibn Ibrahim al-Ansāri, alAthār, (Beirut: Dar al-Kutub al-'Ilmiyyah, 1982), vol. 132. 
view has been encouraged by many contemporary Muslim jurists ${ }^{71}$ to achieve lesser of two evils. When it is evident enough that the adulterer has sincerely repented, he should not be exposed. ${ }^{72}$

Lastly, Abu Hanifah and his disciple Muhammad Ibn Hasan and some scholars among Shafi'iyyah differentiate between the marriage of a man who committed adultery with the woman from the situation where a random man who wishes to marry a fornicating woman. The marriage is valid in the former situation whether the woman is pregnant or not. However, if the man is not the one who committed adultery with her, the marriage contract is invalid. For the consummation, it is valid as long as the woman is not pregnant, though the scholars considered the consummation as impermissible if the woman is pregnant in this situation. $^{73}$

\section{LEGAL IMPLICATIONS OF LEGITIMIZED CHILDREN}

One of the most significant rationales behind having a child born out of wedlock legitimized is to retain his inalienable rights in his family. Once a child is acknowledged by his putative father, he is entitled to enjoy every fundamental right as a legitimate child.

It has been reported that Sulyman Ibn Yasār said that any if a man claims paternity of a child after having illegal sexual intercourse with the child's mother; the child should be attributed to him. He is entitled to inherit that child provided no one claims the paternity of that child. ${ }^{74}$ This verdict has reported from scholars like Ishāq Ibn Rāhawaih, al-Hasan alBasriyy, 'Urwah Ibn al-Zubair, Ibn al-Taymiyyah and Ibn Qayyim. Among contemporary scholars that advocate for this view are Sheikh 'Uthaimain, S'ad Ibn Nāsir al-Khaslān, Khalid al-Muslih, Yusuf al-

${ }^{71}$ Sheikh Salih Ibn Abdullah al-Darwish, Former Justice of General Court in Qatif, Saudi Arabia emphasized this point that avoiding exposing the adulterer is desirable when he has sincerely repented.

${ }^{72}$ Ibn 'Ashûr Muhammad Tāhir, al-Nasab fi al-Fiqh al-Islāmī, (Beirut: Dar alKutub al-'Ilmiyyah, 1978), 13.

${ }^{73}$ Ibid

${ }^{74}$ Sunan al-Dārimī, 3106. 
Shabīli, al-Qadāghi, al-Nāyf al-‘Ajamī, Khalid al-Muqtari, Haniyy alJubairi, Nuruddīn al-Khādimi al-Zawādi Quwaimidi. ${ }^{75}$

\section{THE LEGAL POSITION OF ILLEGITIMATE CHILDREN IN SELECTED MUSLIM COUNTRIES}

Looking at the appalling dilemma facing children born out of wedlock, one would understand that the view that allows legitimation of illegitimate children should be prioritized. For example, the filiation, Article 148 the Moroccan Family Code (Moudawana) of 2004 states that "illegitimate filiation to the father does not produce any of the effects of legitimate filiation., ${ }^{76}$ Parental obligations are single-handedly assumed by a single mother, while the biological father is exempted from taking care of his own biological child. Article 146 states that "Filiation to the mother produces the same effects regardless of whether the children are the result of a legitimate or illegitimate relationship.",77

The law has not, in any way, helped the situation in Morocco. It rather exacerbates it. A study conducted by UNICEF and the Moroccan League for Child Welfare concluded that 4,554 or 1.3 percent of children was abandoned in 2008. In 2012, the INSAF Association revealed that 153 babies were born out of wedlock every day, with 24 ultimately being abandoned. According to the Minister of Justice, Mustapha Ramid, the number of cases of abandoned children examined by Moroccan courts amounted to 5,377 in 2013 . $^{78}$

The mentioned effects of legitimate filiation, as defined by Article 54 , are basic needs such as health care, education, protection and "respect of their identity and its preservation." Most of these children are left

\footnotetext{
75 Nuruddeen Mukhatar al-Khādimi, Nasab al-mawlûd Kharija Rābitah alZawāj, 4.

76 Article 148 the Moroccan Family Code (Moudawana) of 2004 < http://www.aproarab.org/Down/Moroco/3.pdf> accessed 16 November 2018. 77 Article 146, ibid.

78 Amal Ben Hadda, Opinion: Fatherless Children Are Not Illegitimate, < https://www.moroccoworldnews.com/2017/09/227999/opinion-fatherlesschildren-not-illegitimate/> accesed 4 November 2018.
} 
without national identity due to being abandoned by their biological fathers purposely to avoid fatherly responsibilities. ${ }^{79}$

This bizarre condition of illegitimate children has made a court in the North-western Moroccan town of Souk Larbaa to give a landmark ruling in favour of a single mother, granting her the ownership of the family record book, a right exclusively reserved to "Moroccan husbands officially registere in the civil registry," according to the law. However, the ruled was later overturned by the Morocco Court of Appeal. ${ }^{80}$

In Malaysia, the nationwide statistics collected by the National Registration Department (JPN) showed that 4,992 illegitimate children were born to young mothers aged 18 and below in 2017. There were also 120 reported cases of baby dumping in the same year and until June 1664; children were born to underaged mothers. ${ }^{81}$ There were also 120 reported cases of baby dumping in the same year and until June 1664; children were born to underage mothers. ${ }^{82}$ The relevant law on the point is the Births and Deaths Registration Act 1957, a federal law as provided in the discussion below:

${ }^{79}$ Islam Abdelouali, Unknown: Illegitimate children in Morocco struggle for identity, < https://www.moroccoworldnews.com/2015/12/175907/unknownillegitimate-children-in-morocco-struggle-for-identity/> accessed 4 November 2018.

${ }^{80}$ Sonneveld, Nadia. "Seeking Portia and the Duke: Male and Female Judges Dispensing Justice in Paternity Cases in Morocco." Women Judges in the Muslim World: A Comparative Study of Discourse and Practice 15 (2017): 123. 81 Natasha Joibi, Thousands born out of wedlock to underage, < https://www.thestar.com.my/news/nation/2018/07/22/thousands-born-out-ofwedlock-to-underage-malaysians/> accessed 4 November 2018.

${ }^{82}$ Bakar, Md Zawawi Abu, Wan Ibrahim Wan Ahmad, and Mahyuddin Abu Bakar. "Registration Problems of Illegitimate Children among Muslims in Malaysia." Journal of Islamic Studies 5, no. 1 (2017): 9-15. See also Natasha Joibi, Thousands born out of wedlock to underage, < https://www.thestar.com.my/news/nation/2018/07/22/thousands-born-out-ofwedlock-to-underage-malaysians/> accessed 4 November 2018. 
Under Section 13, the name of the person acknowledging himself to be the father of the illegitimate child is to be entered in the register as the child's father provided the mother agrees to it. ${ }^{83}$

Section $13 \mathrm{~A}(1)$ provides that "where the person acknowledging himself to be the father of the child in accordance with Section 13 requests so, the surname may be the surname of that person". ${ }^{84}$

Malaysia is not an exception among other Muslim countries that are facing legal challenges over the fate of illegitimate children. The Malaysian National Council for the Islamic Affairs (MKI) issued fatwa in its $64^{\text {th }}$ Meeting on 27 July 2004 that any child born out of wedlock either as a result of illegal sexual relation or rape, and not from shubhah (doubtful sexual intercourse) or from slavery is illegitimate. The fatwa further reads that any child born less than 6 months from the time of marriage consummation based on the lunar calendar. This is the verdict upheld by other states of Malaysia. ${ }^{85}$

On the contrary, the Syariah Committee of Perlis decided that the $n a s a b$ of a child in the duration of its parents' marriage is less than six months as the following: "A child born less than six months after its mother's marriage is permitted to be associated to mother's husband unless denied by the husband". The National Registration Department of Malaysia (NRD) has relied upon the national fatwa. Thus, any child born out of wedlock according to national fatwa bears the patronymic surname bin Abdullah instead of his father's name. ${ }^{86}$

${ }^{83}$ Abdul-Razak, Suraya, Peter S. Azzopardi, George C. Patton, Ali H. Mokdad, and Susan M. Sawyer. "Child and adolescent mortality across Malaysia's epidemiological transition: a systematic analysis of Global Burden of Disease Data." Journal of Adolescent Health 61, no. 4 (2017): 424-433.

84 Act 299 Births and Deaths Registration ACT 1957 Incorporating all amendments up to 1 January 2006 http://voc.org.my/blog/wpcontent/uploads/2011/12/Birth-and-Death-Registration-Act-Malaysia.pdf> accessed 4 November 2018.

${ }^{85}$ Bakar, Md Zawawi Abu, Wan Ibrahim Wan Ahmad, and Mahyuddin Abu Bakar. "Registration Problems of Illegitimate Children among Muslims in Malaysia." Journal of Islamic Studies 5, no. 1 (2017): 9-15.

${ }^{86}$ Harding, Andrew James, Jaclyn L. Neo, Dian AH Shah, and Wilson Tay Tze Vern. "Malaysia: The state of liberal democracy." International Journal of Constitutional Law 16, no. 2 (2018): 625-634. 
The Malaysian Court of Appeal has challenged the position of National Fatwa when it gave a landmark ruling that that a Muslim child born out of wedlock should be permitted to take on his father's name as his surname. The appellants brought the case because they had sought to register their child with the father's surname, only to be refused by the National Registration Department (NRD) because the child was born less than 6 months after the parents' marriage, which signified that he had been conceived out of wedlock. ${ }^{87}$

Another Muslim country with a dreadful condition of children born out of wedlock is Algeria. These children are no in anyway different from those of unknown filiation. The number of illegitimate children have skyrocketed in recent years. In 2001, 5000 children born out of wedlock was officially recorded by a concerned ministry. ${ }^{88}$ The causes of increase of the number to 7000 in 2007 are largely to be found in illegitimate sexual relationship particularly pre-conjugal sexual relationships. This official figure is, however, believed to have doctored in that the reality in the country indicates that the real number of illegitimate children is considerably higher. ${ }^{89}$

With this enormous challenge, there is no an official recognition of the existence of illegitimate children and the family Code makes no reference to them. ${ }^{90}$ The greatest burden of responsibilities is virtually carried by single mothers, which consequently lead the innocent children to carry social stigma. Bearing the name of his mother is also subject to the consent of the male heir. This is the reason why Algerian orphanages are mostly occupied by illegitimate children. ${ }^{91}$

${ }^{87}$ Ibid.

${ }^{88}$ Barraud, Emilie. "Kafäla and Succession: The Practices of Transfer of the "Parent's" Name and Goods to an Adopted Child." Law and Property in Algeria: Anthropological Perspectives (2018): 164.

${ }^{89}$ Gleave, Robert, and Eugenia Kermeli, eds. Islamic law: Theory and practice. IB Tauris, 2001., 167

${ }^{90}$ Kebir, Yamina. "The Status of Children and Their Protection in Algerian Law (Part II)." YB Islamic \& Middle EL 6 (1999): 156.

${ }^{91}$ Lazreg, Marnia. "Citizenship and gender in Algeria." Gender and citizenship in the Middle East 58 (2000): 66. 


\section{Juristic Tools for Giving Precedence}

The two conflicting views on legitimating illegitimate children are firmly attached to realizing maslahah and warding off evils (mafsadah). Meanwhile, it has been established by Muslim jurists that warding off evils takes precedence over bringing benefits (dar'u al-mafāsid muqaddamun 'ala jalbu al-manāfi'i). However, benefits are, sometimes, derived at the expense of evils, and vice versa. The two matters coincide in most cases, since warding off evils necessitates deriving benefits and obtaining benefits requires warding off evils. ${ }^{92}$ When benefits and harm coincide and the effect of the harm is more grievous, warding off harm takes precedence. However, if the realization of benefits outweighs warding off evils the former takes precedence over the former. ${ }^{93}$

The application of this maxim by classical Muslim jurists appears highly exceptional in establishing legitimacy of children. The application becomes more evident in their efforts to establish legitimacy of children born out of all kinds of doubtful sexual intercourse (wat'u al-shubhah). This is to avoid catastrophic consequences of having fatherless children in the society.

Evidently, the alarming conditions of children born out of wedlock in many Muslim countries is enough for contemporary jurists to re-appraise the issue of legitimizing those innocent children when acknowledged by their putative fathers. Even though the authenticity of the hadith 'alwalad lil firāsh' (the child is to be attributed to the legitimate husband) was authoritatively narrated by al-Bukhari and Muslim, its interpretation remains speculative among Muslim jurists.

In addition, giving precedence to either of the opinion might be circumstantial whereby a judge might be left to his discretion to decide based on maslahah and mafsadah. This is based on the principle of waqāi'u al-ahwāl where a ruling giving a certain person or group differs from others. ${ }^{94}$ This is the position of Al-Qāḍi Abu Ya'la and some jurists

\footnotetext{
${ }^{92}$ Ibn Abdul al-Salām Izz al-Dīn, al-Fawāid fi ikhtișār al-Maqāṣid, (Damascus: Dar al-Fikr, 1995), 50.

${ }^{93}$ Al-Qarāfì, al-Dhakhīrah, vol. 1, 16.

${ }^{94}$ Waqāi'u al-ahwāl could be technically defined as a legal ruling by the Lawgiver related and directed to the act of a particular person or a group of people to a specific situation or occurrence with the permission for its
} 
of the Hanafi School of law that the affiliation of the illegitimate child depends on the verdict of the judge.

\section{CONCLUSION}

The legal discourse over legitimating the illegitimate child has long been a conundrum among the classical and modern jurists. This research has found that opponents of the legitimation of illegitimate children's perspective are quite different; some among them have demonstrated a complete disregard for the existence of scholars' differences on the legitimation of illegitimate children to the extent that this sect of scholars has inadvertently claimed the relative consensus of Muslim scholars. This claim, without any doubt, is completely unfounded for the fact that not only classical books have detailed discourse on the issue but also contemporary ones. The other groups among the opponents admit the existence of scholars' difference over legitimating illegitimate children but they would rather give precedence for the impermissibility over the permissibility.

The research has also found that the major proof offered by the opponents of the legitimation of illegitimate children is the famously cited hadith: "The child belongs to the one on whose bed it is born (Alwalad lil-firassh)". The study has found that both the opponents and proponents of legitimating children born out of wedlock equally agree upon the authenticity of the cited hadith, the argument only erupted over the interpretations. However, the study has revealed that the opponents of the concept of legitimation generalized the verdict issued by the Prophet ((s.a.w)) without considering the circumstance that led to the conflict between the disputing parties and the cause of the conflict. The hadith, therefore, can no longer be used as a proof to prevent a child to be legitimized in cases when a putative father acknowledges the paternity of his child. Besides, it has also been found that other proofs offered by the opponents of the legitimation, particularly from sayings of the Prophet ((s.a.w)) have been proved unsubstantiated by the scholars of hadith.

applicability to another similar situation. See Isa Abdur-Razaq Sarumi and Taofik Abolaji, Critical Analysis of Waqâi'u Al- 'Ayân and Its Implication on Jurist's Dissent, Journal of Islamic Law Journal, Maiduguri State University, Nigeria, 8. 
The finding has shown that the claim of the opponents of legitimation of illegitimate children that preventing putative fathers from claiming their children born out of wedlock would serve as punishment and deterrent to others has been empirically proved unfounded. Empirical studies have shown that some men are taking advantage of women by abandoning them after impregnating them unlawfully as they know the child would not be attributed to them let alone shouldering their responsibilities. Many cases of this nature have been reported by centres for abandoned children and victims of circumstances.

The research has also found that, apart from classical scholars who ventured the permissibility of legitimising illegitimate children, many contemporary Muslim scholars have a strong inclination towards legitimating children born out of wedlock provided the child was not born by a legally married woman. However, in an event where there is a dispute between a legitimate husband and a putative father, the child belongs to the legitimate husband on the basis of the principle of "the child belongs to the owner the bed". Therefore, it is suggested that scholars should look at the reality of our time and give precedence to the opinion that favours the permissibility of legitimising illegitimate children. This would enable children born out of wedlock to be given an identity and would remove social stigma that is unduly attached to them.

Ultimately, with drastic moral degradation that consequently leads to the production of illegitimate children, an enlightenment campaign is recommended to educate people on the negative impact of having children out of wedlock. In addition, Muslim countries should discourage the youth from late marriage to prevent premarital sex that leads to having illegitimate children. 